OPEN ACCESS

Edited by:

Carl J. Rothfels,

University of California, Berkley,

United States

Reviewed by:

Lachezar A. Nikolov,

University of California, Los Angeles,

United States

Angela Jean McDonnell,

Chicago Botanic Garden,

United States

*Correspondence:

Ana M. Bedoya

ambedoya@uw.edu

Specialty section:

This article was submitted to Plant Systematics and Evolution, a section of the journal

Frontiers in Plant Science

Received: 04 June 2019

Accepted: 24 July 2019

Published: 20 August 2019

Citation:

Bedoya AM, Ruhfel BR, Philbrick CT,

Madriñán S, Bove CP, Mesterházy A

and Olmstead RG (2019) Plastid

Genomes of Five Species of

Riverweeds (Podostemaceae):

Structural Organization and Comparative Analysis in Malpighiales.

Front. Plant Sci. 10:1035.

doi: 10.3389/fpls.2019.01035

\section{Plastid Genomes of Five Species of Riverweeds (Podostemaceae): Structural Organization and Comparative Analysis in Malpighiales}

\author{
Ana M. Bedoya ${ }^{1 *}$, Bradley R. Ruhfel ${ }^{2}$, C. Thomas Philbrick ${ }^{3}$, Santiago Madriñán ${ }^{4}$, \\ Claudia P. Bove ${ }^{5}$, Attila Mesterházy ${ }^{6}$ and Richard G. Olmstead ${ }^{1}$
}

${ }^{1}$ Department of Biology and Burke Museum, University of Washington, Seattle, WA, United States, ${ }^{2}$ University of Michigan Herbarium, University of Michigan, Ann Arbor, MI, United States, ${ }^{3}$ Department of Biological and Environmental Sciences, Western Connecticut State University, Danbury, CT, United States, ${ }^{4}$ Laboratorio de Botánica y Sistemática, Departamento de Ciencias Biológicas, Universidad de los Andes, Bogotá, Colombia, ${ }^{5}$ Departamento de Botânica, Museu Nacional, Universidade Federal do Rio de Janeiro, Rio de Janeiro, Brazil, ${ }^{6}$ Directorate of Hortobágy National Park, Debrecen, Hungary

With the advent of next-generation sequencing technologies, whole-plastome data can be obtained as a byproduct of low-coverage sequencing of the plant genomic DNA. This provides an opportunity to study plastid evolution across groups, as well as testing phylogenetic relationships among taxa. Within the order Malpighiales ( 16,000 spp.), the Podostemaceae ( 300 spp.) stand out for their unique habit, living attached to rocks in fast-flowing aquatic habitats, and displaying highly modified morphologies that confound our understanding of their classification, biology, and evolution. In this study, we used genome skimming data to assemble the full plastid genome of 5 species within Podostemaceae. We analyzed our data in a comparative framework within Malpighiales to determine the structure, gene content, and rearrangements in the plastomes of the family. The Podostemaceae have one of the smallest plastid genomes reported so far for the Malpighiales, possibly due to variation in length of inverted repeat (IR) regions, gene loss, and intergenic region variation. We also detected a major inversion in the large single-copy region unique to the family. The uncommon loss or pseudogenization of ycf1 and ycf2 in angiosperms and in land plants in general is also found to be characteristic of Podostemaceae, but the compensatory mechanisms and implications of this and of the pseudogenization of $a c c D$ and rpl23 and loss of rps16 remain to be explained in this group. In addition, we estimated a phylogenetic tree among selected species in Malpighiales. Our findings indicate that the Podostemaceae are a distinct lineage with long branches that suggest faster rates of evolution in the plastome of the group, compared with other taxa in the order. This study lays the foundations for future phylogenomic studies in the family.

Keywords: genome rearrangements, Malpighiales, phylogenomics, plastome, Podostemaceae 


\section{INTRODUCTION}

The plastids have a relatively small, maternally inherited, haploid genome (Sugiura, 1992). It ranges between 120 and $170 \mathrm{~kb}$ in length and is generally composed of a circular structure with two IRs that are mirror images in terms of gene content (IRa and $\mathrm{IRb})$, separated from each other by a large and a small singlecopy regions (LSC and SSC, respectively) (Downie and Palmer, 1992; Sugiura, 1992). Because the plastome encodes genes that are essential for fundamental processes such as photosynthesis and its own replication, it has been generally understood that its genome shows a relatively high degree of conservation in size, structure, and gene content within land plants (Palmer, 1985; Wicke et al., 2011). However, structural rearrangements, gene losses, and expansions and contractions in IRs are widely documented across species (Goulding et al., 1996; Krause, 2011; Weng et al., 2014; Schwarz et al., 2015; Xu et al., 2015; Rabah et al., 2019; Shrestha et al., 2019). Such rearrangements have been relevant in a systematic framework when supporting the monophyly of certain groups (Jansen and Palmer, 1987; Downie and Palmer, 1992; Hoot and Palmer, 1994; Cosner et al., 2004).

With the advent of next-generation sequencing technologies, information from whole-genome data is quickly available at a low cost (Metzker, 2009). Given that plastomes exist in high copy numbers in plant cells, even a genome skimming approach where the nuclear genome is sequenced at low-coverage provides a mechanism to obtain a fully assembled plastome as a byproduct (Straub et al., 2012; Olmstead and Bedoya, 2019). Over the past few years, this has provided the advantage of rapidly generating whole-plastid sequences for a large number of taxa (Daniell et al., 2016). This information has been used to disentangle phylogenetic relationships and to study plastid evolution in selected groups of plants (Ruhfel et al., 2014; Cauz-Santos et al., 2017; Firetti et al., 2017; Gitzendanner et al., 2018; Li and Zheng, 2018; Liu et al., 2018; Li et al., 2019; Lloyd Evans et al., 2019).

Malpighiales is a large order with 36 families, more than 700 genera, and $\sim 16,000$ species (Wurdack and Davis, 2009; The Angiosperm Phylogeny Group, 2016). Full plastid assemblies for 111 species in the families Chrysobalanaceae, Clusiaceae, Erythroxylaceae, Euphorbiaceae, Linaceae, Malpighiacee, Passifloraceae, Salicaceae, and Violaceae currently reside in the NCBI database. In addition, previous studies using wholeplastome data of Passiflora edulis Sims (Cauz-Santos et al., 2017) and of Byrsonima crassifolia (L.) Kunth and Byrsonima coccolobifolia Kunth (Menezes et al., 2018) have provided insights into plastome evolution in the order Malpighiales, reporting rearrangements that are unique to Passifloraceae (Rabah et al., 2019; Shrestha et al., 2019), identifying regions of high sequence divergence, and helping resolve the phylogeny of the group.

Within the morphologically and ecologically diverse group Malpighiales, the family Podostemaceae stands out for its unusual habit (Xi et al., 2012). Riverweeds (as members of this family are also called) are notable for living attached to rocks in fast-flowing water habitats such as river rapids and waterfalls, with flowers that project above the water surface and fruits that develop and shed seeds only in the dry season when the water level is low (van Royen, 1951; Philbrick and Novelo, 1995; Rutishauser, 1995;
Rutishauser, 1997; Philbrick and Novelo, 1998). Much remains to be explored in Podostemaceae despite a number of morphological (van Royen, 1951; Novelo and Philbrick, 1997; Rutishauser et al., 1999; Jäger-Zürn, 2011), developmental (Rutishauser, 1995; Rutishauser, 1997; Jäger-Zürn, 2005, JägerZürn, 2007), and karyological (Oropeza et al., 1998; Oropeza et al., 2002) studies followed by phylogenetic and biogeographical investigations (Kita and Kato, 2001; Ruhfel et al., 2011; Tippery et al., 2011; Koi et al., 2012; Ruhfel et al., 2016).

The extreme conditions experienced by the Podostemaceae have resulted in highly modified vegetative and reproductive morphologies (Eckardt and Baum, 2010). Such forms constitute a taxonomical challenge because the high degree of modification of vegetative and reproductive structures results in a small number of morphological traits that are informative, making the study of the biology and evolution of this group difficult. Given this scenario, genomic data surface as the tool to gain better insight into the evolution of this notable group of plants.

In this study, we present the fully annotated plastid genomes of 5 species of Podostemaceae: Apinagia riedelii Tul., Marathrum capillaceum (Pulle) P. Royen, Marathrum utile Tul., Monostylis capillacea Tul., and Tristicha trifaria (Bory ex Willd.) Spreng. We analyzed our data in a comparative framework within Malpighiales to detect rearrangements and structural characteristics of the plastome of this distinctive family, taking advantage of the data already available in the order. A phylogenetic tree was inferred with whole-plastid data to test relationships and examine sequence divergence and amount of change within the family and order. Our investigation constitutes the first report of a complete nucleotide sequence and structure of the plastid genome in the Podostemaceae.

\section{MATERIALS AND METHODS}

\section{Taxon Sampling, DNA Extraction, and Sequencing}

Samples of A. riedelii, M. capillaceum, M. utile, M. capillacea, and T. trifaria were collected in South America and Africa. Information on collection localities and voucher specimens is shown in Table 1. Together, these samples represent 2 of 3 subfamilies within Podostemaceae (Podostemoideae and Tristichoideae). Subfamily Tristichoideae is sister to a clade comprising the Podostemoideae and the monotypic Weddellinoideae (Kita and Kato, 2001). Therefore, any patterns shared between Tristichoideae and Podostemoideae would most likely be synapomorphies of the Podostemaceae. All species included have a distribution restricted to the Neotropics except for the pantropical T. trifaria.

Total genomic DNA was extracted from silica-dried leaf tissue using a modified CTAB protocol and purified by isopropanol precipitation, or via silica columns (Epoch Life Science, Missouri City, TX, USA) from the aqueous supernatant after chloroform/ isoamyl alcohol purification (Neubig et al., 2014). DNA was run on a $1 \%$ agarose gel to assess DNA quality, and concentration was measured with a Qubit fluorometer using the dsDNA BR Assay Kit (Thermo Fisher Scientific, Waltham, MA, USA). A volume of $90 \mu \mathrm{L}$ of total DNA of M. utile was used to prepare a library with 
TABLE 1 | Provenance, voucher information, and/or GenBank accession numbers of the species in Malpighiales whose plastomes were included in this study.

\begin{tabular}{|c|c|c|c|c|}
\hline Species & Family & Voucher (Herbarium) & GenBank accession no. & Collection locality \\
\hline Hirtella racemosa & Chrysobalanaceae & - & NC_024060 & \\
\hline Garcinia mangostana & Clusiaceae & & NC_036341 & \\
\hline Byrsonima crassifolia & Euphorbiaceae & - & NC_037192 & \\
\hline Passiflora edulis & Passifloraceae & - & NC_034285 & \\
\hline Apinagia riedelii* & Podostemaceae & C.P. Bove 2513 (R) & MN165812 & Brazil, South America \\
\hline Marathrum utile* & Podostemaceae & AMB 497 (ANDES) & MN165814 & Colombia, South America \\
\hline Marathrum capillaceum* & Podostemaceae & C.P. Bove 2493 (R) & MN165813 & Brazil, South America \\
\hline Monostylis capillacea* & Podostemaceae & C.P. Bove 2524 (R) & MN165815 & Brazil, South America \\
\hline Tristicha trifaria* & Podostemaceae & A. Mesterhazy MLI 128(Z) & MN165816 & Mali, Africa \\
\hline Salix purpurea & Salicaceae & - & NC_026722 & \\
\hline Viola seoulensis & Violaceae & - & NC_026986 & \\
\hline
\end{tabular}

Voucher number and collection locality are provided only for those species whose genome was generated in this study $\left.{ }^{*}\right)$.

an average fragment size of 500 bp, using the Kapa Biosystems Hyper prep kit at the QB3 Vincent J. Coates Genomics Sequencing Laboratory at UC Berkeley. Whole-genome shotgun sequencing was also performed at the QB3 Sequencing Laboratory, with 150 bp paired-end reads on 1 lane of an Illumina HiSeq4000. For the remaining species, a volume of $50 \mu \mathrm{L}$ of $50 \mathrm{ng} / \mu \mathrm{L}$ total DNA was used to prepare libraries with average fragment size of $500 \mathrm{bp}$ by Rapid Genomics LLC (Gainesville, FL, USA). Whole-genome sequencing of $150 \mathrm{bp}$ paired-end reads was performed at the same facility by multiplexing samples in 1 lane of an Illumina HiSeqX.

\section{Plastome Assembly and Annotations}

Read quality of paired-end Illumina reads was assessed in FastQC (https://www.bioinformatics.babraham.ac.uk/projects/fastqc/), and adapter sequences were removed using Trimmomatic (Bolger et al., 2014). The pipeline GetOrganelle (Jin et al., 2018) was used to select trimmed reads that corresponded to the plastid using the plastome of Garcinia mangostana L. (Clusiaceae) as a reference. The pipeline was also used to assemble the filtered reads. The annotations of the plastomes of G. mangostana, Manihot esculenta Crantz, and Salix purpurea L. (see Table 1 for GenBank accession numbers) were transferred to the final circular plastid consensus sequences of $A$. riedelii, $M$. utile, $M$. capillaceum, M. capillacea, and T. trifaria with the tool "Annotate from source" in Geneious 9.1.8. (Biomatters Ltd., Auckland, New Zealand). Annotations were manually inspected, and tRNAs were further checked with tRNAscan-SE v2.0 as implemented in GeSeq (Tillich et al., 2017). GC content and boundaries between the IRa IRb, LSC, and SSC regions were determined in Geneious. The diagrams for the circular genomes were obtained with the program OGDRAW (Greiner et al., 2019).

In addition, a second approach to plastome assembly was conducted for M. utile to confirm the output of GetOrganelle. In this second assembly method, plastid filtered reads from GetOrganelle were imported in Geneious 9.1.8. The BBDuk tool was used to trim low-quality bases (Q20) and discard short reads $(<10 \mathrm{bp})$. Reads were further normalized and error corrected using the tool BBNorm with target coverage level 30. A total of 225,896 filtered reads were assembled de novo using the Medium sensitivity/ Fast option in the Geneious Prime de novo assembler. The options "Don't merge variants" and "Produce scaffolds" were left unchecked.
In order to obtain a draft circular plastome, the consensus sequence of the largest contig $(112,008$ bp with $41.9 \mathrm{X}$ mean coverage) was generated. The Geneious Prime plugin "Find Repeats" was used in order to find the IRs. The de novo assembly of short reads in Geneious does not allow a full assembly of both IRs. Instead, it generates a consensus sequence with 1 full IR and the truncated ends of the second IR. For this reason, the latter were trimmed, and the single instance of the full IR was extracted. This extracted IR was reversed complement and concatenated with the previously trimmed consensus sequence of the largest contig. The generated draft genome was used as a reference to map the trimmed paired reads without normalization. This map-toreference assembly was used for single nucleotide polimorphism (SNP) variant calling and to generate a final full circular plastid consensus sequence.

\section{Plastome of Podostemaceae in a Comparative Framework}

To detect differences in the plastomes of the selected species of Podostemaceae with respect to other Malpighiales, we compared the assembled plastid genomes with six species representing six plant families in the order Malpighiales. The families included for comparison represent all the three major clades in Malpighiales (Xi et al., 2012). Accession numbers for the species included in this comparative analysis are listed in Table 1. Visual inspection of rearrangements was performed using progressive Mauve v.2.4.0 with default "seed families" and default values for all other parameters (Darling, 2004). As Mauve cannot handle duplicated regions, one of the IRs of each genome was manually removed following Firetti et al. (2017). The boundaries between the IRa IRb, LSC, and SSC regions in all species were inspected in Geneious using the fully assembled plastids.

We used the software mVista in Shuffle-LAGAN mode to explore variation in gene content within Malpighiales. Garcinia mangostana was used as reference in order to detect possible gene losses, gene variation, or gene conservation in Podostemaceae. Genes with $<50 \%$ similarity were inspected directly in the annotated genomes of Podostemaceae to determine if they were intact, open reading frames. In a separate analysis, $A$. riedelii was used as reference to determine the level of similarity across the whole-plastome sequence in Malpighiales with respect to Podostemaceae. 
In order to test relationships and examine sequence divergence and amount of change within both Malpighiales and Podostemaceae, a phylogenetic tree was inferred using the plastid genomes of all studied species. Averrhoa carambola L. (Oxalidaceae) was used as an outgroup to root the tree. To generate the alignment, in each species the IRb regions were deleted to remove duplicated genes; proteincoding regions, tRNAs, rRNAs, and noncoding regions were extracted, and all genes located on the reverse strand were reversed complemented. The extracted regions were aligned with MAFFT v7.309 in Geneious and then concatenated. The final alignment was 134,969 bp long. The software PartitionFinder2 (Lanfear et al., 2016) was used to select the best partitioning scheme, using a greedy search (Lanfear et al., 2012) in RAxML (Stamatakis, 2014). In the analysis, the three codon positions for each protein-coding region and each tRNA and rRNA were considered separately. Noncoding regions were analyzed together. Maximum likelihood phylogenetic inference was performed using RAxML v8.2 (Stamatakis, 2014), with the "rapid bootstrap analysis and search for best-scoring ML tree option" and 10,000 bootstrap replicates. Per-partition branch lengths were estimated independently.

\section{RESULTS}

\section{Genome Content and Structure in Podostemaceae}

After sequencing, trimming, and selecting reads corresponding only to the plastids in GetOrganelle, 1,581,656 paired reads were recovered for $A$. riedelii, 1,443,458 for M. utile, 225,344 for M. capillaceum, 1,087,996 for M. capillacea, and 313,332 for T. trifaria. The largest plastome was that of $A$. riedelii with a length of $134,912 \mathrm{bp}$ (1177.6X coverage), followed by M. capillaceum with $134,374 \mathrm{bp}$ (190.8X coverage), M. capillacea with $133,944 \mathrm{bp}$ (736.3X coverage), M. utile with 131,951 bp (1264.2X coverage), and $T$. trifaria with $130,285 \mathrm{bp}$ (217.6X coverage). Assembly of the plastome of $M$. utile using Geneious 9.1.8 yielded the same sequence as with GetOrganelle, but mean coverage was lower (514.9X vs. $1264.2 \mathrm{X})$.

All 5 full plastome assemblies in Podostemaceae showed the typical quadripartite structure characteristic of the plastids (see Figure 1). GC content in the IRs is higher than in other regions of the plastid, possibly due to the presence of tRNA genes, as suggested in Dipsacales (Fan et al., 2018). In the 5 species, the 2 IRs span $29.7 \%$ to $31.4 \%$ of the plastome (Table 2).

Gene content was the same across the Podostemaceae species studied, with each genome including 71 protein coding genes, 30 tRNAs, and 4 rRNAs for a total of 105 genes, 13 of which contain 1 intron and 1 (trnK-UUU), which contains 2 introns. Of the total number of genes, $77(\sim 73.33)$ occur in the LSC, 10 $(\sim 9.52 \%)$ in the SSC, and $18(\sim 17.14 \%)$ in the IRs. With regard to protein coding genes, $55(\sim 77.46 \%)$ are included in the LSC, $9(\sim 12.68 \%)$ in the SSC, and $7(\sim 9.86 \%)$ in the IRs. Most tRNAs exist in the LSC region with $28(\sim 73.33 \%)$ tRNAs, followed by 7 $(\sim 23.33 \%)$ in the IRs, and only $1(\sim 3.33 \%)$ in the SSC region. All rRNAs were found in the IRs. A full account of gene content for the Podostemaceae species is listed in Table 3.

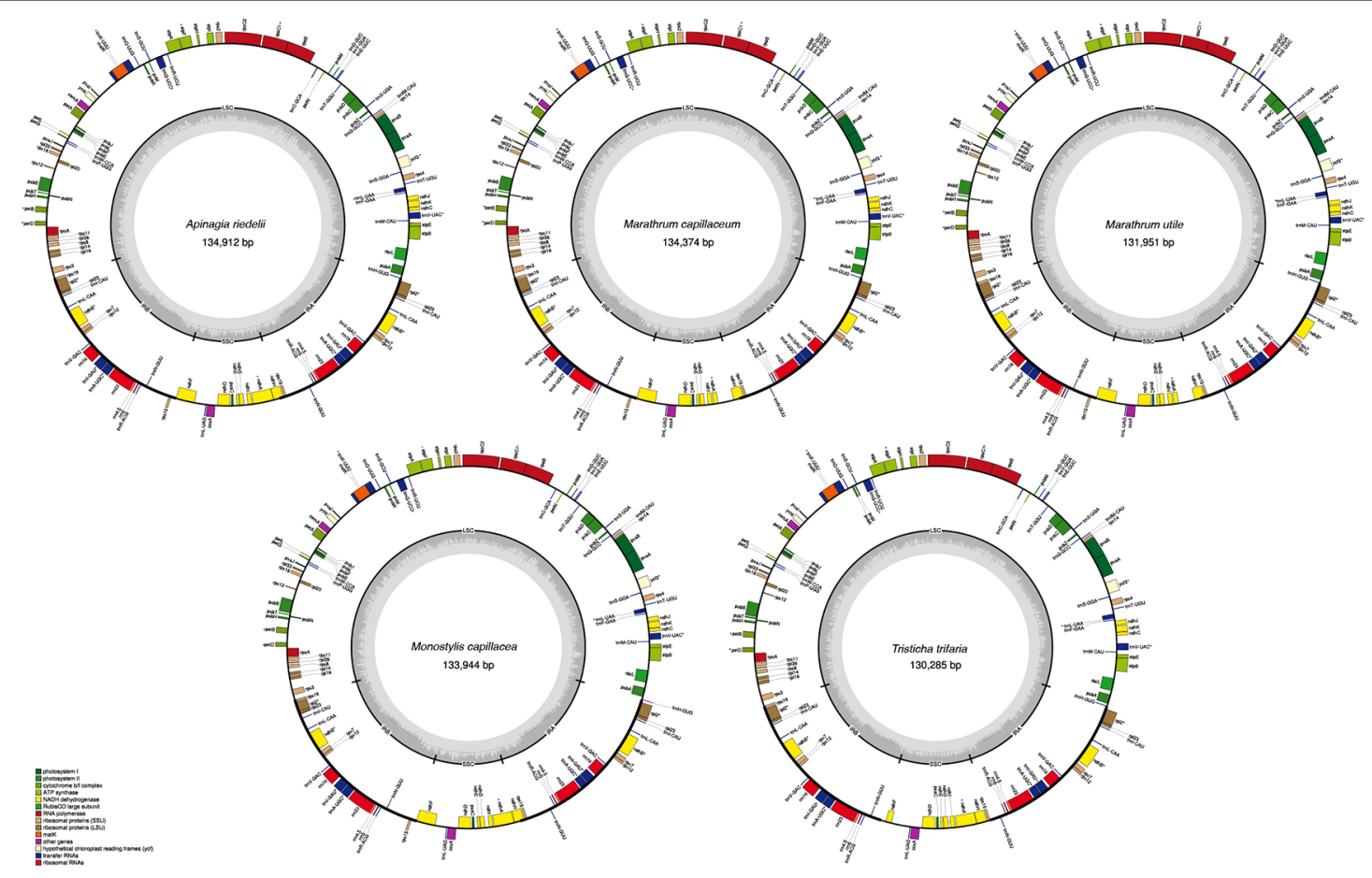

FIGURE 1 | Plastid genomes of the 5 species of Podostemaceae included in this study. Only functional genes are drawn, and GC content graphs are included as dark gray bars toward the center of each diagram. Intron-containing genes are marked with $\left(^{*}\right)$. 
TABLE 2 | Structural information of the plastid genomes of Podostemaceae, Clusiaceae, Malpighiaceae, Chrysobalanaceae, Violaceae, Passifloraceae, and Salicaceae. The percentages of the total size of the genome that corresponds to each region are included.

\begin{tabular}{|c|c|c|c|c|c|}
\hline Species & Family & $\begin{array}{c}\text { Plastome genome } \\
\text { size (bp) }\end{array}$ & $\begin{array}{l}\text { IRs length } \\
\text { (bp) }\end{array}$ & $\begin{array}{l}\text { SSC length } \\
\text { (bp) }\end{array}$ & $\begin{array}{l}\text { LSC length } \\
\text { (bp) }\end{array}$ \\
\hline Apinagia riedelii & Podostemaceae & 134,912 & $21,049 \times 2(\sim 30.1 \%)$ & 12,437 ( 8.9\%) & $85,377(\sim 61 \%)$ \\
\hline Monostylis capillacea & Podostemaceae & 133,944 & $21,026 \times 2(\sim 31.4)$ & 12,395 ( 9.3\%) & $79,497(\sim 59.4 \%)$ \\
\hline Marathrum utile & Podostemaceae & 131,951 & $19,945 \times 2(\sim 30.2 \%)$ & 12,283 ( 9.3\%) & 79,778 ( 60.5\%) \\
\hline Marathrum capillaceum & Podostemaceae & 134,374 & $21,041 \times 2(\sim 31.3)$ & 12,302 ( 9.2\%) & $79,990(\sim 59.5 \%)$ \\
\hline Tristicha trifaria & Podostemaceae & 130,285 & $19,349 \times 2(\sim 29.7)$ & 12,662 ( 9.7\%) & $78,925(\sim 60.6 \%)$ \\
\hline Garcinia mangostana & Clusiaceae & 158,179 & $27,009 \times 2(\sim 34.1 \%)$ & 17,704 ( 11.2\%) & $86,457(\sim 54.7 \%)$ \\
\hline Byrsonima crassifolia & Malpighiaceae & 160,212 & $26,975 \times 2(\sim 33.7 \%)$ & $17,814(\sim 11.1 \%)$ & $88,448(\sim 55.2 \%)$ \\
\hline Hirtella racemosa & Chrysobalanaceae & 162,891 & 26,866 × $2(\sim 33 \%)$ & 19,915 ( 12.2\%) & $89,244(\sim 54.8 \%)$ \\
\hline Viola seoulensis & Violaceae & 156,507 & $26,404 \times 2(\sim 33.7 \%)$ & $18,008(\sim 11.5 \%)$ & $85,691(\sim 54.8 \%)$ \\
\hline Passiflora edulis & Passifloraceae & 151,406 & $26,152 \times 2(\sim 34.5 \%)$ & $13,378(\sim 8.8 \%)$ & $85,724(\sim 56.6 \%)$ \\
\hline Salix purpurea & Salicaceae & 155,590 & $27,459 \times 2(\sim 35.3 \%)$ & $16,220(\sim 10.4 \%)$ & $84,452(\sim 54.3 \%)$ \\
\hline
\end{tabular}

TABLE 3 | Gene content in all Podostemaceae species included in this study.

\begin{tabular}{lll}
\hline Gene function & Gene group & Gene name \\
\hline Self-replication & Ribosomal RNA genes & rrn 4.5, rrn5, rrn16, rrn23
\end{tabular}
Transfer RNA genes $\quad$ trnA-UGC*, trnC-GCA, trnD-GUC, trnE-UUC, trnFGAA, trnfM-CAU, trnG-GCC, trnG-UCC*, trnH-GUG, trnICAU, trnI-GAU*, trnK-UUU*, trnL-CAA, trnL-UAA*, trnLUAG, trnM-CAU, trnN-GUU, trnP-UGG, trnQ-UUG, trnRACG, trnR-UCU, trnS-GCU, trnS-GGA, trnS-UGA, trnT-GGU, $\operatorname{trnT}$-UGU, trnV-GAC, trnV$U A C^{\star}, \operatorname{trnW}-C C A, \operatorname{trnY}-G \cup A$ rps2, rps3, rps4, rps7, rps8, rps11, rps12, rps14, rps15, rps 18, rps19

rpl2*, rp/14, rp/16, rp/20, rp/33, rp/36

rроA, rроB, rpoC1*, rрoC2

RNA polymerase subunits

Photosynthesis Subunits of NADH dehydrogenase

Subunits of photosystem I Subunits of photosystem II

Subunits of cytochrome b/f complex

Subunits of ATP synthase

Large subunit of Rubisco

Other

Maturase

matk

protein

C-type cytochrome $\operatorname{ccs} A$

synthesis

ORFs

$y c f 4$

$n d h A^{*}, \boldsymbol{n d} \mathbf{h} \boldsymbol{B}^{*}, n d h C, n d h D$, $n d h E, n d h F, n d h G, n d h H, n d h l$, ndhJ, ndhK

psaA, psaB, psaC, psal, psaJ, ycf3*

$p s b A, p s b B, p s b C, p s b D, p s b E$ psbF, psbH, psbl, psbJ, psbK, $p s b L, p s b M, p s b N, p s b T, p s b Z$ $\operatorname{pet} A, \operatorname{pet} B^{*}, \operatorname{pet} D^{*}$, oetG, petL, petN

atpA, atpB, atpE, atpF*, atpH,
atpl
rbcL
matk
cemA
ccsA
ycf4

Genes in bold correspond to genes that are located in the IRs and hence are duplicated. Genes that contain introns are marked with asterisk (*).

\section{Plastome of Podostemaceae in a Comparative Framework Within Malpighiales}

Information on plastid genome size and size of the IRa, IRb, LSS, and SSC regions in all species shows that the Podostemaceae possess the smallest genome of the species included in this study (Table 2). This reduction is relatively uniform across the IRs, LSS, and SSC, as the proportions of each region in the plastid remain fairly similar in Malpighiales. However, in Podostemaceae, the LSC region did not shrink as much as the SSC and IRs regions, occupying a slightly larger percentage of the plastid in Podostemaceae (Table 2). Inspection of the plastomes of Podostemaceae and selected members of the Malpighiales with Mauve shows a large inversion of $\sim 49,000 \mathrm{bp}$ in the LSC region. The inversion is located between the genes $r b c L$ and $\operatorname{trnK}$. This rearrangement is unique in Podostemaceae with respect to the other Malpighiales species inspected (Figure 2). Other rearrangements are seen in P. edulis as previously reported (Cauz-Santos et al., 2017; Shrestha et al., 2019).

A comparison of border positions of the four plastid regions in the full organelle sequences across the 11 species studied is shown in Figure 3. The LSC/IRb border is located within the rps19 gene, creating a 220-bp truncated copy (pseudogene) in the IRa in all the Podostemaceae species studied, as well as in G. mangostana and Hirtella racemosa Lam. In Viola seoulensis Nakai, this duplicated fragment is only $68 \mathrm{bp}$, in line with previous work (Menezes et al., 2018). Variations in the length of the IRb in B. crassifolia, S. purpurea, and P. edulis caused the $\mathrm{LSC} / \mathrm{IRb}$ border to fall within the rpl22 gene in the former two species, and between rpl22 and rps19 in P. edulis. This created a pseudogene in the IRa of both B. crassifolia and S. purpurea. In Podostemaceae and in G. mangostana, the boundaries of $\operatorname{trnH}$ and the truncated copy of $r p s 19$ overlap by $7 \mathrm{bp}$ in the IRa. In all species except in P. edulis, trnH-GUG is the first gene in the LSC region. This exception has been proposed to be caused by a small inversion at the beginning of the LSC region containing the $p s b A$ and $t r n H-G U G$ genes (Cauz-Santos et al., 2017). The SSC/ IRa is located within the $n d h H$ gene in A. riedelii, M. capillaceum, M. capillacea, and M. utile, creating a pseudogene in the IRb. 


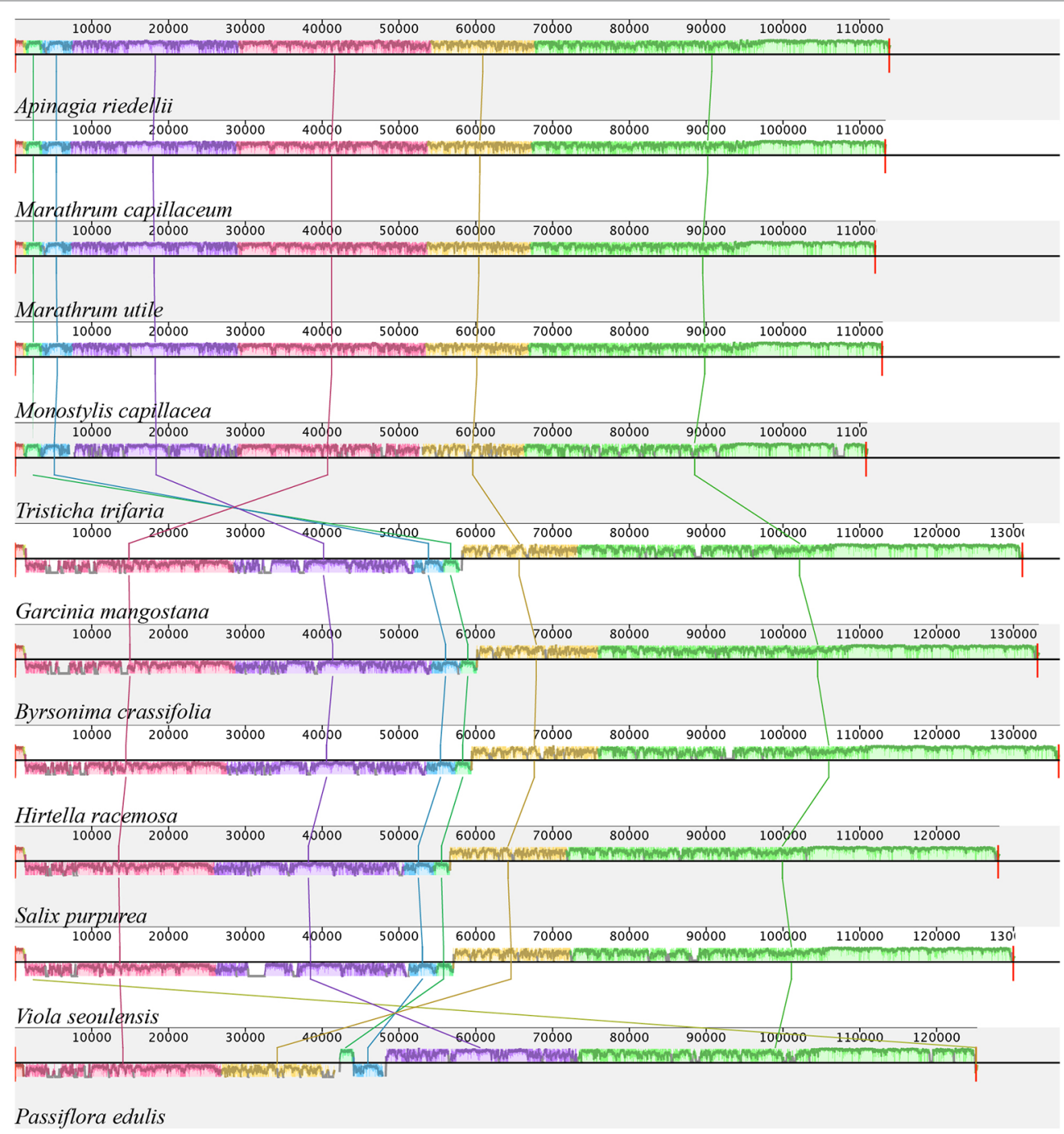

FIGURE 2 | Alignment resulted from Mauve showing a large inversion shared by all Podostemaceae. Color bars indicate syntenic blocks, and connecting lines indicate correspondence of blocks across genomes.

This border is shifted to the rps 15 gene in T. trifaria and P. edulis, where a small fragment of this gene $(<20$ bp long) spans the IRa and is duplicated in the IRb. In the remaining species, the SSC/ IRa border falls in the $y c f 1$ gene, which is located downstream of the $n d h H$ and rps15. As a consequence, a $y c f 1$ pseudogene is produced in the IRb. This gene is reduced to a pseudogene in Podostemaceae.

An alignment of 11 species in six families with $G$. mangostana used as reference is shown in Figure 4. In this alignment, the large inversion previously identified was reinverted in order to enhance visualization and allow gene content comparison. We found that species in Podostemaceae share the loss of the rps16 gene with most other Malpighiales, except for B. crassifolia (Malpighiaceae), where the gene is present. Similarly, the Podostemaceae are like other Malpighiales in the retention of the atpF Group II intron, which is absent only in P. edulis. On the contrary, the gene for the subunit of acetyl-Co-A-carboxylase $(a c c D)$ is highly divergenet in the Podostemaceae and not in frame in $\mathrm{M}$. capillacea and in $\mathrm{M}$. capillaceum. The large subunit of ribosome protein ( $r p l 23)$, and the chloroplast open reading frames $y c f 1$ and $y c f 2$ are reduced to pseudogenes only in Podostemaceae and in P. edulis (Cauz-Santos et al., 2017) (Figure 3).

The analysis performed in $\mathrm{mVista}$ using $A$. riedelii as reference is shown in Figure 5. Apinagia riedelii, $M$. capillaceum, M. utile, and M. capillacea, all members of the Podostemoideae, show high similarity across their plastome. In fact, the percentage similarity supports that all four species belonging to this subfamily are more similar to each other than any of them are to Tristicha, in the subfamily Tristichoideae. As expected, similarity is higher in coding regions than in intergenic sequences.

Phylogenetic analysis was conducted using an optimal scheme with 53 partitions as resulted from PartitionFinder2. Information on partitions and substitution models is included 


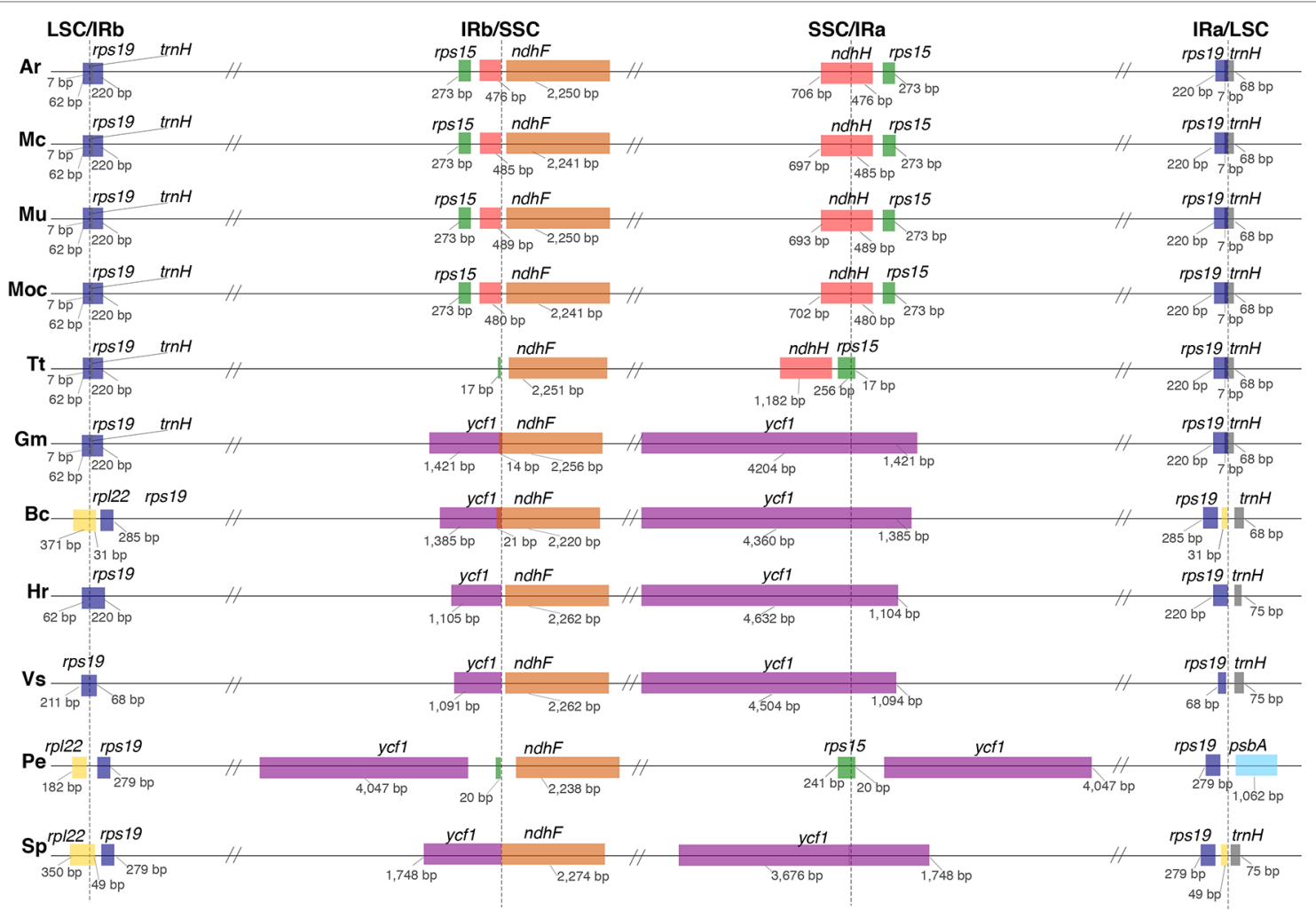

FIGURE 3 | Comparison of border positions of the 4 plastid regions (LSC, IRb, SSC, IRa) among plastomes of Ar, Apinagia riedelii; Mc, Marathrum capillaceum; Mu Marathrum utile; MoC, Monostylis capillacea; Tt, Tristicha trifaria; Gm, Garcinia mangostana; Bc, Byrsonima crassifolia; Hr, Hirtella racemosa; Vs, Viola seoulensis; Pe, Passiflora edulis; Sp, Salix purpurea. Functional genes and truncated fragments are shown with the same color. The sizes of fragments in genes that are located in a boundary are shown.

in the Supplementary Material. Among the Podostemaceae, the Podostemoideae are supported as monophyletic and sister to T. trifaria (Figure 6). The phylogeny also shows that the branches leading to taxa in the Podostemaceae from the common ancestor of Malpighiales are much longer than the branches leading to other taxa within the order. Garcinia mangostana (Clusiaceae) is supported as sister to Podostemaceae (100\% bootstrap), in line with previous work, but this clade was found as sister to H. racemosa (Chrysobalanaceae), contrary to previous work (Xi et al., 2012; Menezes et al., 2018) where Chrysobalanaceae is found as more closely related to Malpighiaceae. Salix purpurea, P. edulis, and V. seoulensis are supported as a clade (100\% bootstrap), and the relationships among them are in agreement with Xi et al., 2012. However, B. crassifolia (Malpighiaceae) is reconstructed as sister to this clade ( $85 \%$ bootstrap), and as mentioned above, this contradicts previous published work (Xi et al., 2012; Menezes et al., 2018).

\section{DISCUSSION}

The 130,218- to 134,912 -bp size range of the plastome reported in this study for Podostemaceae species falls within the average size of angiosperm plastomes (Sugiura, 1992). However, it is notable that the full plastid genomes generated here for the family are among the smallest reported so far in Malpighiales (Shrestha et al., 2019; https://www.ncbi.nlm.nih.gov/genome).

It has been proposed that plastome size variation could be caused by variation in length of IR regions, gene loss, and intergenic region variation (Palmer et al., 1987; Wolfe et al., 1992; Wakasugi et al., 1994; Chumley et al., 2006; Xiao-Ming et al., 2017). We have reported here that the IRs in the Podostemaceae are $\sim 6 \mathrm{~kb}$ smaller than in the other Malpighiales used for comparison (Table 2), and we have also reported the loss of $r p s 16$ and reduction to pseudogenes of $a c c D$ (in some species of Podostemaceae), $y c f 1$, and $y c f 2$. However, the average size of the plastome of Podostemaceae is smaller than the other Malpighiales examined here by 16 to $28 \mathrm{~kb}$, and this difference cannot be explained by a smaller length of the IRs and by gene losses alone. Intergenic region variation as well as intron loss also contribute to this difference in plastome size, considering that the number of introns reported for Podostemaceae is smaller than in P. edulis (CauzSantos et al., 2017) and that intergenic regions are the most variable in our comparative study (Figure 4). Indeed, when calculating the total length of intergenic regions in Podostemaceae and of the other species in Malpighiales analyzed here, the Podostemaceae are shorter by $\sim 5.5 \mathrm{kp}$ on average. This implies that all three processes responsible for genome size variation mentioned above are responsible for the reduction in size of the plastomes in Podostemaceae. 


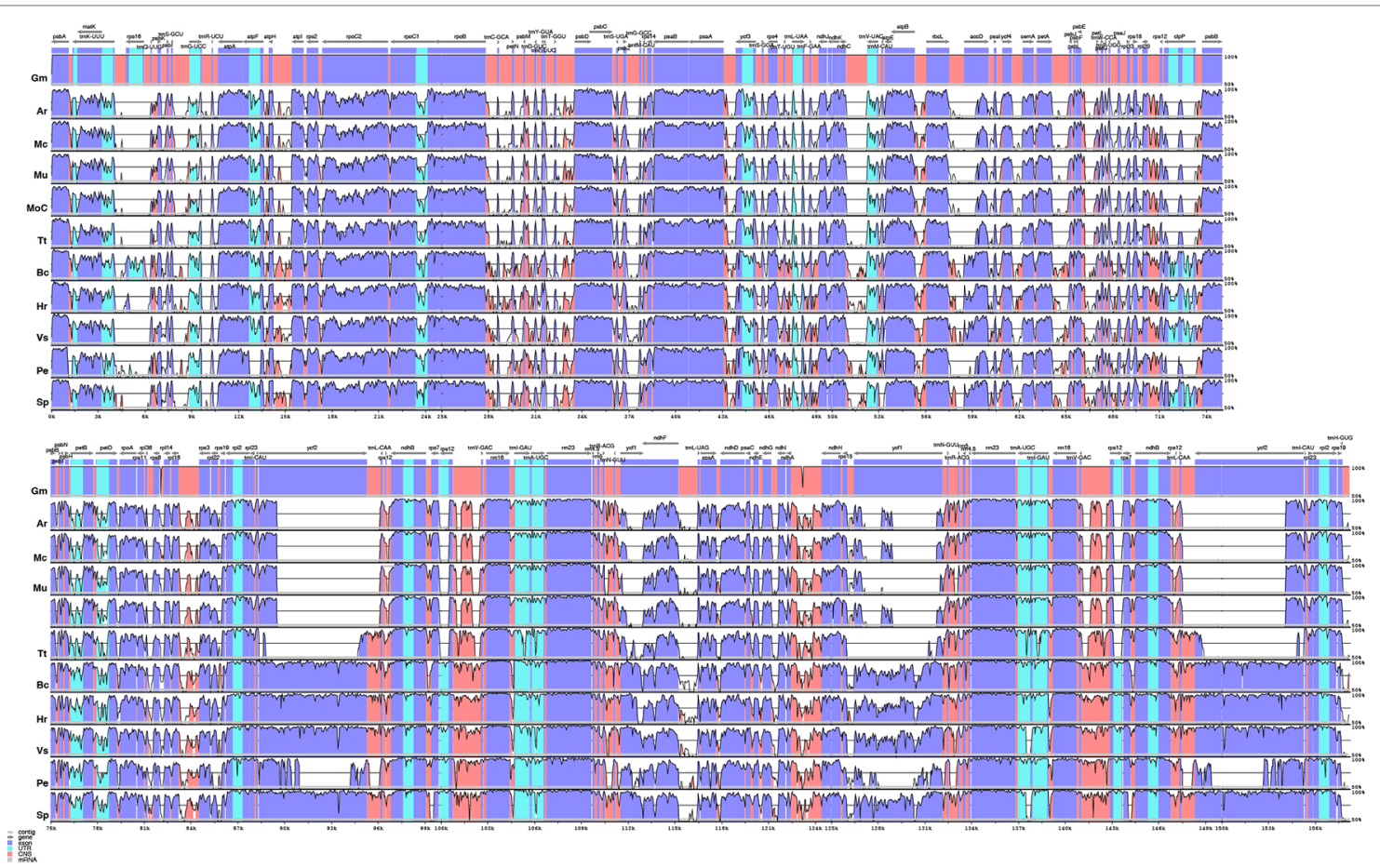

FIGURE 4 | Comparison of percentage identity of plastomes in mVista using Garcinia mangostana (Gm) as reference. Ar, Apinagia riedelii; Mc, Marathrum capillaceum; Mu, Marathrum utile; Moc, Monostylis capillacea; Tt, Tristicha trifaria; Bc, Byrsonima crassifolia; Hr, Hirtella racemosa; Vs, Viola seoulensis; Pe, Passiflora edulis; Sp, Salix purpurea. The vertical axis corresponds to the percentage identity (50\%-100\%), while the horizontal axis shows the position of each region within the locus. Arrows indicate the transcription of annotated genes in the reference genome. Genome regions are color coded.

The large rearrangement in the LSC region appears to be a synapomorphy of Podostemaceae, but this observation should be confirmed in more species in the family before this trait is considered to be of any systematic relevance. Other structural rearrangements have been reported in Malpighiales such as the 3 inversions in the LSC region in P. edulis (Cauz-Santos et al., 2017), high rates of rearrangements in Passiflora (Rabah et al., 2019; Shrestha et al., 2019), and a single small inversion in the LSC region of Hevea brasiliensis (Tangphatsornruang et al., 2011). We found no evidence of other structural rearrangements within Podostemaceae.

Evaluation of the boundaries of the 4 plastid regions across all species suggests that the locations of borders of the IRs in the Podostemoideae sampled are fairly conserved, but differ to a small degree in all 5 species studied. This is consistent with the IR boundaries being in a dynamic state in most angiosperms (Goulding et al., 1996). A change in length in the IRs of T. trifaria, which are slightly smaller than in Podostemoideae (Table 2), could be interpreted as either a contraction of the IRs in T. trifaria or an expansion of the regions in Podostemoideae. Either way, expansions and contractions of the IRs have occurred more than once in Malpighiales, creating pseudogenes (Cauz-Santos et al., 2017; Menezes et al., 2018; Shrestha et al., 2019). Podostemaceae are no exception to these variations in length, but as mentioned above, these do not seem to be the sole reason why Podostemaceae have one of the smallest plastomes in Malpighiales.
With regard to gene content, the retention of the atpF Group II intron is considered an ancestral condition in land plants with a single gain within the streptophytes, before the origin of land plants, followed by losses in charophytes (Daniell et al., 2008). This intron has also been found to be lost from the plastome of members of Euphorbiacceae, Phyllanthaceae, Elatinaceae, Lophopixidaceae, and Passifloraceae (Daniell et al., 2008). Podostemaceae is a lineage within Malpighiales that retains the ancestral state for presence of the atpF group II intron.

Targeted gene disruptions in tobacco have identified four plastid genes with essential functions beyond photosynthesis: $a c c D, c l P$, $y c f 1$, and $y c f 2$ (Drescher et al., 2000; Kuroda and Maliga, 2003; Kode et al., 2005; Kikuchi et al., 2013; Parker et al., 2014; Dong et al., 2015). Even though these four genes are retained in the plastid genomes of most angiosperms, including parasitic species that are chlorophylldeficient (dePamphilis and Palmer, 1990; Funk et al., 2007; Jansen et al., 2007; Parker et al., 2014), there are multiple other parasitic, mycoheterotrophic plants, and taxa outside Malpighiales where these genes are missing from the plastids (Kim, 2004; Magee et al., 2010; Lei et al., 2016; Graham et al., 2017). As reported here, some of these genes may have been reduced to pseudogenes independently in Podostemaceae and in Passiflora (Shrestha et al., 2019).

The pseudogenization or loss of genes from the plastids has been reported to be a consequence of it being transferred to the nuclear genome (Jansen et al., 2011; Cauz-Santos et al., 2017). This event of plastid gene transfer remains to be examined in Podostemaceae. The rps16 gene is considered to be present in 


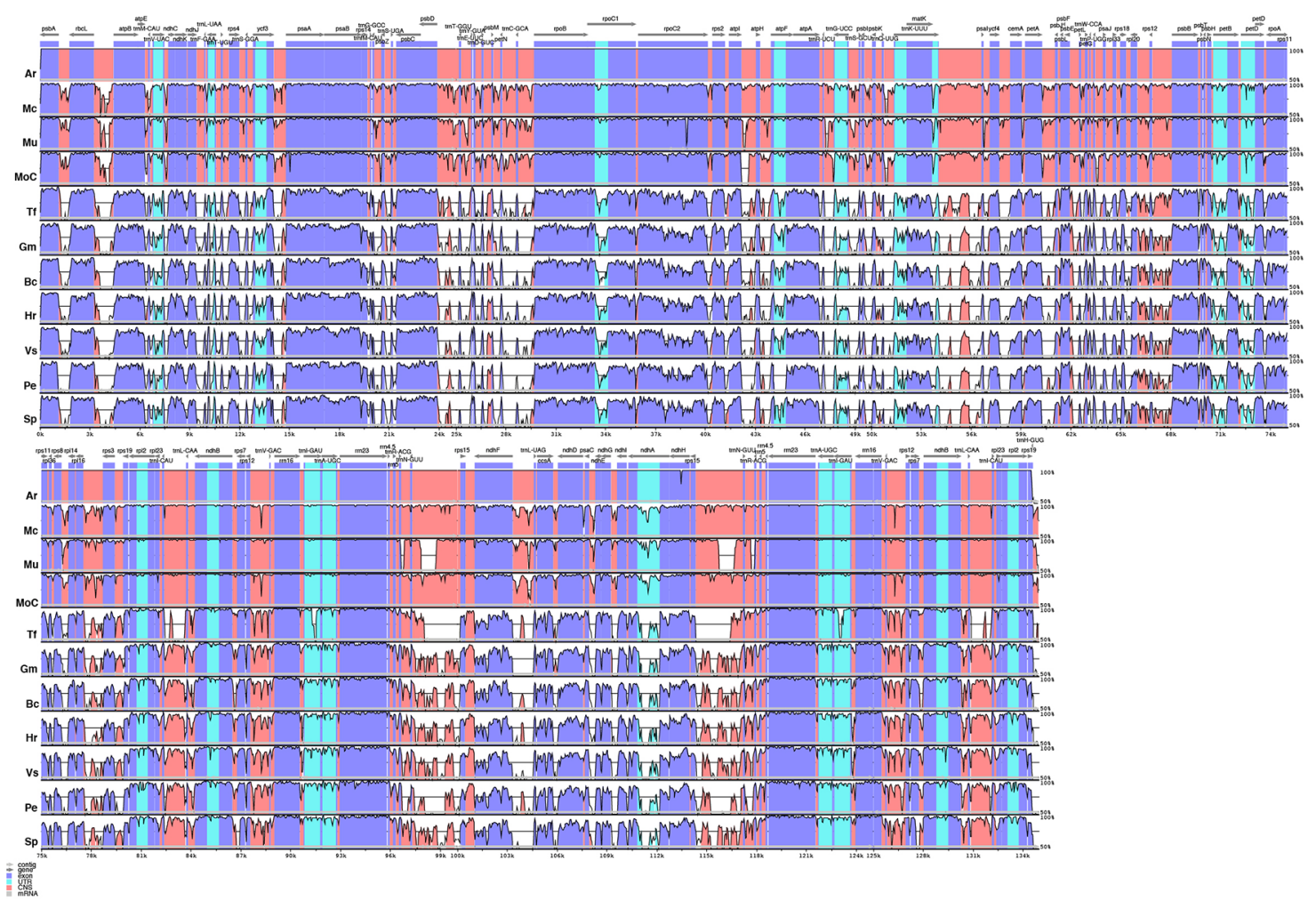

FIGURE 5 | Comparison of percentage identity of plastomes in mVista using Apinagia riedelii (Ar) as reference. Mc, Marathrum capillaceum; Mu, Marathrum utile; Moc, Monostylis capillacea; Tt, Tristicha trifaria; Gm, Garcinia mangostana; Bc, Byrsonima crassifolia; Hr, Hirtella racemosa; Vs, Viola seoulensis; Pe, Passiflora edulis; Sp, Salix purpurea. The vertical axis corresponds to the percentage identity $(50 \%-100 \%)$, while the horizontal axis shows the position of each region within the locus. Arrows indicate the transcription of annotated genes in the reference genome. Genome regions are color coded.

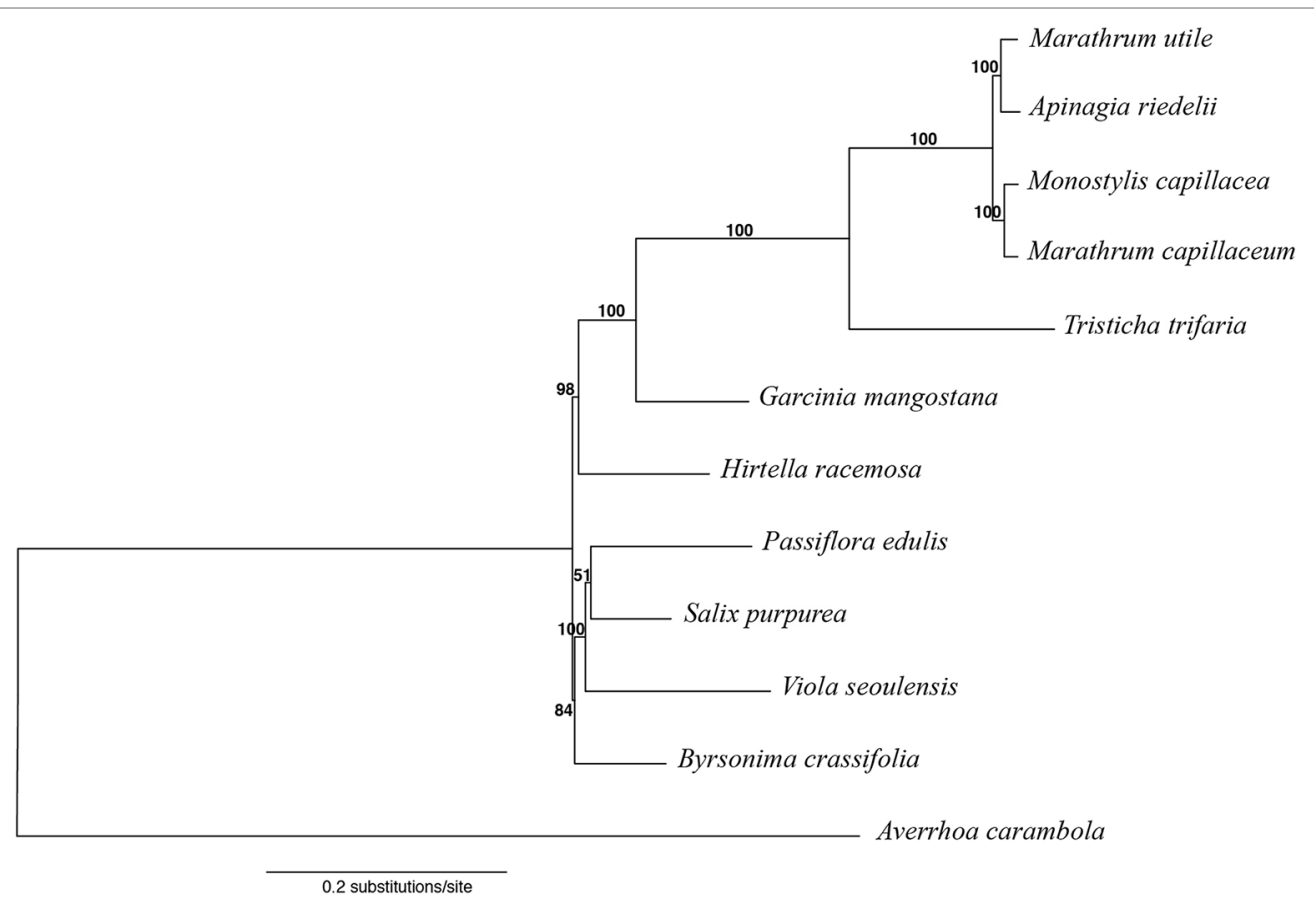

FIGURE 6 | Maximum likelihood tree obtained with RAXML, using Averrhoa carambola as outgroup for rooting. Bootstrap support is shown above branches. 
the common ancestor of land plants (Daniell et al., 2016) and is found in the plastomes of most angiosperms (Ueda et al., 2008). However, it has been repeatedly reported as lost in Malpighiales (Asif et al., 2010; Daniell et al., 2008; Jansen et al., 2007; Steane, 2005), including our findings of it being missing in Podostemaceae and in other angiosperms (Keller et al., 2017). The multiple losses of $r p s 16$ from the plastids have been explained by the fact that the nuclear encoded rps16 is dually targeted to the mitochondria and the plastids (Ueda et al., 2008; Keller et al., 2017). This has also been reported to be responsible for the pseudogenization of rpl23 (Bubunenko et al., 1994). Examination of the presence of this gene in the mitochondrial and nuclear DNA would be necessary to test if this explanation also applies to Podostemaceae.

The $y c f 1$ gene is one of the largest and most variable genes in the plastid genome of land plants, and as mentioned above, it has been proposed to be fundamental for plant function as a key component of the general protein import channel (Dong et al., 2015; Kikuchi et al., 2013). It is rarely missing from the plastome of autotrophic plant lineages, with the exception of Poaceae, some species of Passiflora, Vaccinium macrocarpon, and some species of Erodium (de Vries et al., 2015). However, this gene is more commonly lost from the organellar genome of parasitic, mycoheterotrophic, and carnivorous plant taxa such as Orobanche purpurea, species in Droseraceae, and a number of orchids (Guisinger et al., 2010; Parker et al., 2014; Graham et al., 2017; Nevill et al., 2019). Our finding that $y c f 1$ is pseudogenized in Podostemaceae adds this group to one of the unique autotrophic lineages in angiosperms where this is known to have occurred. However, the mechanisms that compensate for this loss and the implications of it remain to be studied.

The high similarity across the plastome in the subfamily Podostemoideae (Figure 5), which are more similar to each other than they are to T. trifaria, is explained by the fact that the members of this subfamily share a more recent common ancestor (Figure 6). The short branches within Podostemoideae indicate that fewer changes have accumulated since the species diverged, possibly as a consequence of recent speciation events with little subsequent sequence evolution (Soltis et al., 2019). Additionally, the fact that the branches leading to taxa in the Podostemaceae from their common ancestor in Malpighiales are much longer than the branches leading to other taxa within the order is an indicator of faster rates of evolution in the plastome of riverweeds, giving support to previous suggestions (Ruhfel et al., 2016).

Long branches depicting accelerated rates of evolution have been reported in parasitic plants, where multiple changes in the chloroplast respond to a switch from an autotrophic to a heterotrophic metabolism, causing a reduced function of the genome (Young and dePamphilis, 2005; Stefanovic et al., 2007; Lemaire et al., 2011; Givnish et al., 2018). However, the switch from autotrophy to heterotrophy has not occurred in the Podostemaceae. Instead, faster rates of evolution in Podostemaceae could be explained by their rapid life cycle and shorter generation times; most species of Podostemaceae are annual herbs because they depend on the water level to complete their life cycle, dying and shedding seeds in the dry season when the water level is low. This inverse correlation between evolutionary rate and generation time has been suggested for plants as well as for other organisms such as mammals (Bromham et al., 1996; Verdú, 2002; Smith and Donoghue, 2008). Interestingly, the same pattern of long branches observed in Podostemaceae has been found in the Hydrostachyaceae (Cornales) based on phylogenetic analysis using plastid data (Olmstead et al., 2000; Albach et al., 2001; Fan and Xiang, 2003), and the Hydrostachyaceae are the only angiosperm family that shares the unique habit of Podostemaceae (Jäger-Zürn, 1998; Qiu-Yun Xiang, 1999; Rutishauser et al., 2005). However, faster rates of evolution have also been correlated to other life history traits such as plant height, genome size, and age at first reproduction among others (Lehtonen and Lanfear, 2014; Bromham et al., 2015). Which factors are responsible for faster rates of evolution in Podostemaceae and whether they (it) has anything to do with the habit of Podostemaceae and Hydrostachyaceae, remain to be determined.

The phylogenetic relationships found here for the selected species of Malpighiales (Figure 6) are in line with previous work where Salicaceae and Passifloraceae are in a clade that shares a more recent common ancestor with Violaceae (and Goupiaceae), whereas Clusiaceae and Podostemaceae are together in a separate clade (Xi et al., 2012; Cai et al., 2019). The relationships within Podostemaceae also follow previous work that suggest that Marathrum is paraphyletic (Tippery et al., 2011; Philbrick et al., 2018), calling for a revision of the classification of the genus. Our results (Figure 6) also follow a recent study (Cai et al., 2019) in the placement of Chrysobalanaceae, using 5,113 orthology clusters to infer a phylogeny of Malpighiales. These results contradict previous works (Xi et al., 2012; Menezes et al., 2018) that have placed Chrysobalanaceae and Malpighiaceae as more closely related to one another than they are to any of the other families in the Malpighiales included here. The incongruence across data sets is in the deep nodes within the order, reinstating the difficulty in reconstructing deep nodes in Malpighiales (Wurdack and Davis, 2009).

\section{CONCLUSIONS}

In this study, we assembled five full plastid genomes of species in Podostemaceae and analyzed them in a comparative framework within Malpighiales. We detected an important inversion in the LSC region that could be of systematic relevance as a synapomorphy of the group and also described slight variations in the length of the IRs in all the species included in the study. The plastomes of the family are among the smallest reported to date in the order Malpighiales, and we suggest that this small size is a result of a combination of variation in length of IR regions, gene loss, and intergenic region variation and intron loss. Gene content is the same within the Podostemaceae, and some of the gene loss and pseudogenization events reported are common in angiosperms (e.g., rps16, rpl23, and $a c c D$ ), whereas others are very rare (e.g., $y c f 1$ and $y c f 2$ ). The mechanisms that compensate for these losses and the implications of their occurrence in Podostemaceae remain a subject of study. Our results suggest an accelerated rate of evolution for the group and reinstate the difficulty in the inferring relationship in deep nodes in 
Malpighiales. Ultimately, this study provides insights into the structure and evolution of plastomes in Podostemaceae and lays the foundations for phylogenomic studies in the family.

\section{DATA AVAILABILITY}

Whole-plastid genome sequences are deposited in GenBank, and accession numbers are provided in Table 1 . The records can be found in GenBank (https://www.ncbi.nlm.nih. gov/genbank/).

\section{AUTHOR CONTRIBUTIONS}

$\mathrm{AB}$ and $\mathrm{RO}$ designed the study and wrote the manuscript. $\mathrm{AB}$ analyzed the data and conducted field work in Colombia, collecting Marathrum utile. BR and CP contributed tissue samples, sequences, and comments. SM provided help with collecting permits and sampling logistics in the field in Colombia. CB contributed tissue samples of $A$. riedelii, Marathrum capillaceum and Monostylis capillacea from Brazil, as we all comments to the manuscript. AM provided tissue samples of Tristica trifaria from Africa.

\section{FUNDING}

$A B$ was supported by the Sargent award from the Biology department at the University of Washington, the Colciencias fellowship for Graduate studies (Doctorados en el Exterior-679), and the BSA and ASPT Research Grants for graduate students. This work used the Vincent J. Coates Genomics Sequencing Laboratory at UC Berkeley, supported by NIH S10 OD018174

\section{REFERENCES}

Albach, D. C., Soltis, D. E., Chase, M. W., and Soltis, P. S. (2001). Phylogenetic placement of the enigmatic angiosperm. Hydrostachys. Taxon 50, 781. doi: $10.2307 / 1223707$

Asif, M. H., Mantri, S. S., Sharma, A., Srivastava, A., Trivedi, I., Gupta, P., et al. (2010). Complete sequence and organisation of the Jatropha curcas (Euphorbiaceae) chloroplast genome. Tree Genet. Genomes 6, 941-952. doi: 10.1007/s11295-010-0303-0

Bolger, A. M., Lohse, M., and Usadel, B. (2014). Trimmomatic: a flexible trimmer for Illumina sequence data. Bioinformatics 30, 2114-2120. doi: 10.1093/ bioinformatics/btu170

Bromham, L., Hua, X., Lanfear, R., and Cowman, P. F. (2015). Exploring the relationships between mutation rates, life history, genome size, environment, and species richness in flowering plants. Am. Nat. 185, 507-524. doi: 10.1086/680052

Bromham, L., Rambaut, A., and Harvey, P. H. (1996). Determinants of rate variation in mammalian DNA sequence evolution. J. Mol. Evol. 43, 610-621. doi: 10.1007/BF02202109

Bubunenko, M. G., Schmidt, J., and Subramanian, A. R. (1994). Protein substitution in chloroplast ribosome evolution: a eukaryoticcytosolic protein has replaced its organelle homologue(L23) in spinach. J. Mol. Biol. 240, 28-41.

Cai, L., Xi, Z., Amorim, A. M., Sugumaran, M., Rest, J. S., Liu, L., et al. (2019). Widespread ancient whole-genome duplications in Malpighiales coincide with Eocene global climatic upheaval. New Phytol. 221, 565-576. doi: 10.1111/ nph.15357
Instrumentation Grant. BR was supported by a National Science Foundation Grant (DEB-1754329). Collection of some tissue samples was done with support of the National Science Foundation Grants (DEB-0444589 and DEB-1754199) and Connecticut State University-AAUP research grants to $\mathrm{CP}$, and Conselho Nacional de Desenvolvimento Científico e Tecnológico (CNPq) grants PROTAX 562251/2010-3, REFLORA 563534/2010-9, and Productivity Grant (307870/2014-6) to CB. Open Access page charges covered in part by the Universidad de los Andes research results publication fund CI-001, and by the University of Washington and University of Michigan.

\section{ACKNOWLEDGMENTS}

We are thankful to Dr. Adam Leaché at the University of Washington for providing laboratory space, use of equipment, and comments on the manuscript. We thank Dr. Kurt Neubig for his generous help with the sequencing of $A$. riedelii, $M$. capillaceum, M. capillacea, and T. trifaria. Dr. Nuebig and Dr. Lucas Majure offered valuable comments on the manuscript. We also thank Dr. Sasa Stefánovic for comments on chloroplast evolution and loss of the $y f c 1$ gene. Dr. Carl J. Rothfels and Dr. Lachezar A. Nikolov at UCLA, and Dr. Angela Jean McDonnell at Chicago Botanical Garden provided important comments, reviews and edits that improved the initial version of this manuscript. Maria Paula Contreras provided assistance in the field in Colombia.

\section{SUPPLEMENTARY MATERIAL}

The Supplementary Material for this article can be found online at: https://www.frontiersin.org/articles/10.3389/fpls.2019.01035/ full\#supplementary-material

Cauz-Santos, L. A., Munhoz, C. F., Rodde, N., Cauet, S., Santos, A. A., Penha,H. A., et al. (2017). The chloroplast genome of Passiflora edulis (Passifloraceae) assembled from long sequence reads: structural organization and phylogenomic studies in Malpighiales. Front. Plant. Sci. 8, 334. doi: 10.3389/fpls.2017.00334

Chumley, T. W., Palmer, J. D., Mower, J. P., Fourcade, H. M., Calie, P. J., Boore, J. L., et al. (2006). The complete chloroplast genome sequence of Pelargonium $\times$ hortorum: organization and evolution of the largest and most highly rearranged chloroplast genome of land plants. Mol. Biol. Evol. 23, 2175-2190. doi: 10.1093/ molbev/msl089

Cosner, M. E., Raubeson, L. A., and Jansen, R. K. (2004). Chloroplast DNA rearrangements in Campanulaceae: phylogenetic utility of highly rearranged genomes. BMC Evol. Biol. 4, 27. doi: 10.1186/1471-2148-4-27

Daniell, H., Lin, C.-S., Yu, M., and Chang, W.-J. (2016). Chloroplast genomes: diversity, evolution, and applications in genetic engineering. Genome Biol. 17, 134. doi: 10.1186/s13059-016-1004-2

Daniell, H., Wurdack, K. J., Kanagaraj, A., Lee, S.-B., Saski, C., and Jansen, R. K. (2008). The complete nucleotide sequence of the cassava (Manihot esculenta) chloroplast genome and the evolution of atpF in Malpighiales: RNA editing and multiple losses of a group II intron. Theor. Appl. Genet. 116, 723-737. doi: 10.1007/ s00122-007-0706-y

Darling, A. C. E. (2004). Mauve: multiple alignment of conserved genomic sequence with rearrangements. Genome Res. 14, 1394-1403. doi: 10.1101/ gr.2289704

de Vries, J., Sousa, F. L., Bölter, B., Soll, J., and Gould, S. B. (2015). YCF1: a green TIC? Plant Cell. 27, 1827-1833. doi: 10.1105/tpc.114.135541 
dePamphilis, C. W., and Palmer, J. D. (1990). Loss of photosynthetic and chlororespiratory genes from the plastid genome of a parasitic flowering plant. Nature 348, 337-339. doi: 10.1038/348337a0

Dong, W., Xu, C., Li, C., Sun, J., Zuo, Y., Shi, S., et al. (2015). Ycf1, the most promising plastid DNA barcode of land plants. Sci Rep. 5, 8348. doi: 10.1038/srep08348

Downie, S. R., and Palmer, J. D (1992). "Use of chloroplast DNA rearrangements in reconstructing plant phylogeny," in Molecular Systematics of Plants. Eds. P. S. Soltis, D. E. Soltis, and J. J. Doyle (Boston, MA: Springer US), 14-35. doi: 10.1007/978-1-4615-3276-7_2

Drescher, A., Ruf, S., Calsa, T., Carrer, H., and Bock, R. (2000). The two largest chloroplast genome-encoded open reading frames of higher plants are essential genes. Plant J. 22, 97-104. doi: 10.1046/j.1365-313x.2000.00722.x

Eckardt, N. A., and Baum, D. (2010). The Podostemad puzzle: the evolution of unusual morphology in the Podostemaceae. Plant Cell. 22, 2104-2104. doi: $10.1105 /$ tpc. 110.220711

Fan, C., and Xiang, Q.-Y. J. (2003). Phylogenetic analyses of Cornales based on $26 S$ rRNA and combined $26 S$ rDNA-matK-rbcL sequence data. Am. J. Bot. 90, 1357-1372. doi: 10.3732/ajb.90.9.1357

Fan, W.-B., Wu, Y., Yang, J., Shahzad, K., and Li, Z.-H. (2018). Comparative chloroplast genomics of Dipsacales species: insights into sequence variation, adaptive evolution, and phylogenetic relationships. Front. Plant Sci. 9, 689. doi: $10.3389 /$ fpls.2018.00689

Firetti, F., Zuntini, A. R., Gaiarsa, J. W., Oliveira, R. S., Lohmann, L. G., and Van Sluys, M.-A. (2017). Complete chloroplast genome sequences contribute to plant species delimitation: a case study of the Anemopaegma species complex. Am. J. Bot. 104, 1493-1509. doi: 10.3732/ajb.1700302

Funk, H. T., Berg, S., Krupinska, K., Maier, U. G., and Krause, K. (2007). Complete DNA sequences of the plastid genomes of two parasitic flowering plant species, Cuscuta reflexa and Cuscuta gronovii. BMC Plant Biol. 7, 45. doi: 10.1186/1471-2229-7-45

Gitzendanner, M. A., Soltis, P. S., Wong, G. K.-S., Ruhfel, B. R., and Soltis, D. E. (2018). Plastid phylogenomic analysis of green plants: a billion years of evolutionary history. Am. J. Bot. 105, 291-301. doi: 10.1002/ajb2.1048

Givnish, T. J., Zuluaga, A., Spalink, D., Soto Gomez, M., Lam, V. K. Y., Saarela, J. M., et al. (2018). Monocot plastid phylogenomics, timeline, net rates of species diversification, the power of multi-gene analyses, and a functional model for the origin of monocots. Am. J. Bot. 105, 1888-1910. doi: 10.1002/ajb2.1178

Goulding, S. E., Wolfe, K. H., Olmstead, R. G., and Morden, C. W. (1996). Ebb and flow of the chloroplast inverted repeat. MGG Mol. Gen. Genet. 252, 195-206. doi: 10.1007/BF02173220

Graham, S. W., Lam, V. K. Y., and Merckx, V. S. F. T. (2017). Plastomes on the edge: the evolutionary breakdown of mycoheterotroph plastid genomes. New Phytol. 214, 48-55. doi: 10.1111/nph.14398

Greiner, S., Lehwark, P., and Bock, R. (2019). OrganellarGenomeDRAW (OGDRAW) version 1.3.1: expanded toolkit for the graphical visualization of organellar genomes. Nucleic Acids Res. 47, W59-W64. doi:10.1093/nar/ gkz238

Guisinger, M. M., Chumley, T. W., Kuehl, J. V., Boore, J. L., and Jansen, R. K. (2010). Implications of the plastid genome sequence of Typha (Typhaceae, Poales) for understanding genome evolution in Poaceae. J. Mol. Evol. 70, 149-166. doi: 10.1007/s00239-009-9317-3

Hoot, S. B., and Palmer, J. D. (1994). Structural rearrangements, including parallel inversions, within the chloroplast genome of Anemone and related genera. J. Mol. Evol. 38, 274-281. doi: 10.1007/BF00176089

Jäger-Zürn, I. (1998). "Anatomy of Hydrostachyaceae," in Extreme adaptations in angiospermous hydrophytes. Eds. E. Landolt, I. Jager-Zurn, and R. A. A. Schnell (Berlin: Borntraeger), 129-196.

Jäger-Zürn, I. (2005). Shoot apex and spathella: two problematical structures of Podostemaceae-Podostemoideae. Plant Syst. Evol. 253, 209-218. doi: 10.1007/ s00606-005-0297-5

Jäger-Zürn, I. (2007). The shoot apex of Podostemaceae: de novo structure or reduction of the conventional type? Flora 202, 383-394. doi: 10.1016/j. flora.2007.04.003

Jäger-Zürn, I. (2011). Neglected features of probable taxonomic value in Podostemaceae: the case of Polypleurum. Flora 206, 38-46. doi: 10.1016/j. flora.2010.01.008

Jansen, R. K., Cai, Z., Raubeson, L. A., Daniell, H., dePamphilis, C. W., LeebensMack, J., et al. (2007). Analysis of 81 genes from 64 plastid genomes resolves relationships in angiosperms and identifies genome-scale evolutionary patterns. PNAS 104, 19369-19374. doi: 10.1073/pnas.0709121104

Jansen, R. K., and Palmer, J. D. (1987). A chloroplast DNA inversion marks an ancient evolutionary split in the sunflower family (Asteraceae). PNAS 84, 5818-5822. doi: 10.1073/pnas.84.16.5818

Jansen, R. K., Saski, C., Lee, S.-B., Hansen, A. K., and Daniell, H. (2011). Complete plastid genome sequences of three Rosids (Castanea, Prunus, Theobroma): evidence for at least two independent transfers of $r p l 22$ to the nucleus. Mol. Biol. Evol. 28, 835-847. doi: 10.1093/molbev/msq261

Jin, J.-J., Yu, W.-B., Yang, J.-B., Song, Y., Yi, T.-S., and Li, D.-Z. (2018). GetOrganelle: a simple and fast pipeline for de novo assembly of a complete circular chloroplast genome using genome skimming data. bioRxiv. doi: $10.1101 / 256479$

Keller, J., Rousseau-Gueutin, M., Martin, G. E., Morice, J., Boutte, J., Coissac, E., et al. (2017). The evolutionary fate of the chloroplast and nuclear rps16 genes as revealed through the sequencing and comparative analyses of four novel legume chloroplast genomes from Lupinus. DNA Res. 24, 343-358. doi: 10.1093/dnares/dsx006

Kikuchi, S., Bédard, J., Hirano, M., Hirabayashi, Y., Oishi, M., Imai, M., et al. (2013). Uncovering the protein translocon at the chloroplast inner envelope membrane. Science 339, 571-574. doi: 10.1126/science. 1229262

Kim, K.-J. (2004). Complete chloroplast genome sequences from Korean Ginseng (Panax schinseng Nees) and comparative analysis of sequence evolution among 17 vascular plants. DNA Res. 11, 247-261. doi: 10.1093/dnares/11.4.247

Kita, Y., and Kato, M. (2001). Infrafamilial phylogeny of the aquatic angiosperm Podostemaceae inferred from the nucleotide sequences of the matK gene. Plant Biol. 3, 156-163. doi: 10.1055/s-2001-12895

Kode, V., Mudd, E. A., Iamtham, S., and Day, A. (2005). The tobacco plastid accD gene is essential and is required for leaf development: essential plastid gene. Plant J. 44, 237-244. doi: 10.1111/j.1365-313X.2005.02533.x

Koi, S., Kita, Y., Hirayama, Y., Rutishauser, R., Huber, K. A., and Kato, M. (2012). Molecular phylogenetic analysis of Podostemaceae: implications for taxonomy of major groups. Bot. J. Linn. Soc. 169, 461-492. doi: 10.1111/j.1095-8339.2012.01258.x

Krause, K. (2011). Piecing together the puzzle of parasitic plant plastome evolution. Planta 234, 647-656. doi: 10.1007/s00425-011-1494-9

Kuroda, H., and Maliga, P. (2003). The plastid $c l p P 1$ protease gene is essential for plant development. Nature 425, 86-89. doi: 10.1038/nature01909

Lanfear, R., Calcott, B., Ho, S. Y. W., and Guindon, S. (2012). PartitionFinder: combined selection of partitioning schemes and substitution models for phylogenetic analyses. Mol. Biol. Evol. 29, 1695-1701. doi: 10.1093/molbev/ mss020

Lanfear, R., Frandsen, P. B., Wright, A. M., Senfeld, T., and Calcott, B. (2016). PartitionFinder 2: new methods for selecting partitioned models of evolution for molecular and morphological phylogenetic analyses. Mol. Biol. Evol. 43, 772-773. doi: $10.1093 / \mathrm{molbev} / \mathrm{msw} 260$

Lehtonen, J., and Lanfear, R. (2014). Generation time, life history and the substitution rate of neutral mutations. Biol. Lett. 10, 20140801. doi: 10.1098/ rsbl.2014.0801

Lei, W., Ni, D., Wang, Y., Shao, J., Wang, X., Yang, D., et al. (2016). Intraspecific and heteroplasmic variations, gene losses and inversions in the chloroplast genome of Astragalus membranaceus. Sci. Rep. 6, 21669. doi: 10.1038/srep21669

Lemaire, B., Huysmans, S., Smets, E., and Merckx, V. (2011). Rate accelerations in nuclear $18 S$ rDNA of mycoheterotrophic and parasitic angiosperms. J. Plant Res. 124, 561-576. doi: 10.1007/s10265-010-0395-5

Li, B., and Zheng, Y. (2018). Dynamic evolution and phylogenomic analysis of the chloroplast genome in Schisandraceae. Sci. Rep. 8, 9285. doi: 10.1038/ s41598-018-27453-7

Li, Z.-H., Ma, X., Wang, D.-Y., Li, Y.-X., Wang, C.-W., and Jin, X.-H. (2019). Evolution of plastid genomes of Holcoglossum (Orchidaceae) with recent radiation. BMC Evol. Biol. 19, 63. doi: 10.1186/s12862-019-1384-5

Liu, H., He, J., Ding, C., Lyu, R., Pei, L., Cheng, J., et al. (2018). Comparative analysis of complete chloroplast genomes of Anemoclema, Anemone, Pulsatilla, and Hepatica revealing structural variations among genera in tribe Anemoneae (Ranunculaceae). Front. Plant. Sci. 9, 1097. doi: 10.3389/ fpls.2018.01097

Lloyd Evans, D., Joshi, S. V., and Wang, J. (2019). Whole chloroplast genome and gene locus phylogenies reveal the taxonomic placement and relationship of 
Tripidium (Panicoideae: Andropogoneae) to sugarcane. BMC Evol. Biol. 19, 33. doi: 10.1186/s12862-019-1356-9

Magee, A. M., Aspinall, S., Rice, D. W., Cusack, B. P., Semon, M., Perry, A. S., et al. (2010). Localized hypermutation and associated gene losses in legume chloroplast genomes. Genome Res. 20, 1700-1710. doi: 10.1101/gr.111955.110

Menezes, A. P. A., Resende-Moreira, L. C., Buzatti, R. S. O., Nazareno, A. G., Carlsen, M., Lobo, F. P., et al. (2018). Chloroplast genomes of Byrsonima species (Malpighiaceae): comparative analysis and screening of high divergence sequences. Sci. Rep. 8, 2210. doi: 10.1038/s41598-018-20189-4

Metzker, M. L. (2009). Sequencing technologies-the next generation. Nat. Rev. Genet. 11, 31. doi: $10.1038 / \mathrm{nrg} 2626$

Neubig, K., Whitten, W., Abbott, J., Elliott, S., Soltis, D. E., and Soltis, P. S., (2014). "Variables affecting DNA preservation in archival DNA specimens," in DNA Banking in the 21st Century: Proceedings of the U.S. Workshop on DNA Banking. Eds. W. L. Applequist and L. M. Campbell (St. Louis: The William L. Brown Center at the Missouri Botanical Garden).

Nevill, P. G., Howell, K. A., Cross, A. T., Williams, A. V., Zhong, X., Tonti-Filippini, J., et al. (2019). Plastome-wide rearrangements and gene losses in carnivorous Droseraceae. Genome Biol. Evol. 11, 472-485. doi: 10.1093/gbe/evz005

Novelo, R. A., and Philbrick, C. T. (1997). Taxonomy of Mexican Podostemaceae. Aquat. Bot. 57, 275-303. doi: 10.1016/S0304-3770(96)01122-9

Olmstead, R. G., and Bedoya, A. M. (2019). Whole genomes: the holy grail. A commentary on molecular phylogenomics of the tribe shoreeae (Dipterocarpaceae) using whole plastid genomes. Ann. Bot. 123, iv-v. doi: 10.1093/aob/mcz055

Olmstead, R. G., Kim, K.-J., Jansen, R. K., and Wagstaff, S. J. (2000). The phylogeny of the Asteridae sensu lato based on chloroplast $n d h F$ gene sequences. Mol. Phylogenet. Evol. 16, 96-112. doi: 10.1006/mpev.1999.0769

Oropeza, N., Mercado-Ruaro, P., Novelo, R. A., and Thomas Philbrick, C. (1998). Karyomorphological studies of Mexican species of Marathrum (Podostemaceae). Aquat. Bot. 62, 207-211. doi: 10.1016/S0304-3770(98)00086-2

Oropeza, N., Palomino, G., Novelo, R. A., and Philbrick, C. T. (2002). Karyomorphological studies in Oserya, Vanroyenella and Tristicha (Podostemaceae sensu lato). Aquat. Bot. 73, 163-171. doi: 10.1016/S0304-3770(02)00018-9

Palmer, J. D. (1985). "Evolution of chloroplast and mitochondrial DNA in plants and algae," in Molecular Evolutionary Genetics. Ed. R. MacIntyre (New York: Plenum Press), 131-240. doi: 10.1007/978-1-4684-4988-4_3

Palmer, J. D., Nugent, J. M., and Herbon, L. A. (1987). Unusual structure of Geranium chloroplast DNA: a triple-sized inverted repeat, extensive gene duplications, multiple inversions, and two repeat families. PNAS 84, 769-773. doi: $10.1073 /$ pnas.84.3.769

Parker, N., Wang, Y., and Meinke, D. (2014). Natural variation in sensitivity to a loss of chloroplast translation in Arabidopsis. Plant Physiol. 166, 2013-2027. doi: 10.1104/pp.114.249052

Philbrick, C. T., and Novelo, R. A. (1995). New World Podostemaceae: ecological and evolutionary enigmas. Brittonia 47, 210. doi: 10.2307/2806959

Philbrick, C. T., and Novelo, R. A. (1998). Flowering phenology, pollen flow, and seed production in Marathrum rubrum (Podostemaceae). Aquat. Bot. 62, 199206. doi: 10.1016/S0304-3770(98)00090-4

Philbrick, C. T., Ruhfel, B. R., and Bove, C. P. (2018). Contributions to the taxonomy of Rhyncholacis (Podostemaceae): evidence of monophyly, description of a new species, and transfer of the monotypic Macarenia. Phytotaxa 357, 107. doi: 10.11646/phytotaxa.357.2.3

Qiu-Yun Xiang, J. (1999). Systematic affinities of Grubbiaceae and Hydrostachyaceae within Cornales-insights from $r b c L$ sequences. Harv. Pap. Bot. 4, 527-541. https://www.jstor.org/stable/41761589

Rabah, S. O., Shrestha, B., Hajrah, N. H., Sabir, M. J., Alharby, H. F., Sabir, M. J., et al. (2019). Passiflora plastome sequencing reveals widespread genomic rearrangements. J. Syst. Evol. 57, 1-14. doi: 10.1111/jse.12425

Ruhfel, B. R., Bittrich, V., Bove, C. P., Gustafsson, M. H. G., Philbrick, C. T., Rutishauser, R., et al. (2011). Phylogeny of the clusioid clade (Malpighiales): evidence from the plastid and mitochondrial genomes. Am. J. Bot. 98, 306-325. doi: 10.3732/ajb.1000354

Ruhfel, B. R., Bove, C. P., Philbrick, C. T., and Davis, C. C. (2016). Dispersal largely explains the Gondwanan distribution of the ancient tropical clusioid plant clade. Am. J. Bot. 103, 1117-1128. doi: 10.3732/ajb.1500537

Ruhfel, B. R., Gitzendanner, M. A., Soltis, P. S., Soltis, D. E., and Burleigh, J. (2014). From algae to angiosperms-inferring the phylogeny of green plants
(Viridiplantae) from 360 plastid genomes. BMC Evol. Biol. 14, 23. doi: 10.1186/1471-2148-14-23

Rutishauser, R. (1995). Developmental patterns of leaves in Podostemaceae compared with more typical flowering plants: saltational evolution and fuzzy morphology. Can. J. Botany 73, 1305-1317. doi: 10.1139/b95-142

Rutishauser, R. (1997). Structural and developmental diversity in Podostemaceae (river-weeds). Aquat. Bot. 57, 29-70. doi: 10.1016/S0304-3770(96)01120-5

Rutishauser, R., Novelo, R. A., and Philbrick, C. T. (1999). Developmental morphology of New World Podostemaceae: Marathrum and Vanroyenella. Int. J. Plant Sci. 160, 29-45. doi: 10.1086/314097

Rutishauser, R., Pfeifer, E., Novelo, R. A., and Thomas Philbrick, C. (2005). Diamantina lombardii-an odd Brazilian member of the Podostemaceae. Flora 200, 245-255. doi: 10.1016/j.flora.2004.09.004

Schwarz, E. N., Ruhlman, T. A., Sabir, J. S. M., Hajrah, N. H., Alharbi, N. S., Al-Malki, A. L., et al. (2015). Plastid genome sequences of legumes reveal parallel inversions and multiple losses of rps 16 in papilionoids: parallel inversions and rps16 losses in legumes. J. Syst. Evol. 53, 458-468. doi: 10.1111/ jse. 12179

Shrestha, B., Weng, M.-L., Theriot, E. C., Gilbert, L. E., Ruhlman, T. A., Krosnick, S. E., et al. (2019). Highly accelerated rates of genomic rearrangements and nucleotide substitutions in plastid genomes of Passiflora subgenus Decaloba. Mol. Phylogenet. Evol. 138, 53-64. doi: 10.1016/j.ympev. 2019.05.030

Smith, S. A., and Donoghue, M. J. (2008). Rates of molecular evolution are linked to life history in flowering plants. Science 322, 86-89. doi: 10.1126/ science.1163197

Soltis, P. S., Folk, R. A., and Soltis, D. E. (2019). Darwin review: angiosperm phylogeny and evolutionary radiations. P. Roy. Soc. B-Biol. Sci. 286, 20190099. doi: 10.1098/rspb.2019.0099

Stamatakis, A. (2014). RAxML version 8: a tool for phylogenetic analysis and post-analysis of large phylogenies. Bioinformatics 30, 1312-1313. doi: 10.1093/ bioinformatics/btu033

Steane, D. A. (2005). Complete nucleotide sequence of the chloroplast genome from the Tasmanian Blue Gum, Eucalyptus globulus (Myrtaceae). DNA Res. 12, 215-220. doi: 10.1093/dnares/dsi006

Stefanovic, S., Kuzmina, M., and Costea, M. (2007). Delimitation of major lineages within Cuscuta subgenus Grammica (Convolvulaceae) using plastid and nuclear DNA sequences. Am. J. Bot. 94, 568-589. doi: 10.3732/ ajb.94.4.568

Straub, S. C. K., Parks, M., Weitemier, K., Fishbein, M., Cronn, R. C., and Liston, A. (2012). Navigating the tip of the genomic iceberg: next-generation sequencing for plant systematics. Am. J. Bot. 99, 349-364. doi: 10.3732/ajb.1100335

Sugiura, M. (1992). “The chloroplast genome," in 10 Years Plant Molecular Biology. Eds. R. A. Schilperoort and L. Dure (Dordrecht: Springer Netherlands), 149168. doi: 10.1007/978-94-011-2656-4_10

Tangphatsornruang, S., Uthaipaisanwong, P., Sangsrakru, D., Chanprasert, J., Yoocha, T., Jomchai, N., et al. (2011). Characterization of the complete chloroplast genome of Hevea brasiliensis reveals genome rearrangement, RNA editing sites and phylogenetic relationships. Gene 475, 104-112. doi: 10.1016/j. gene.2011.01.002

The Angiosperm Phylogeny Group. (2016). An update of the angiosperm phylogeny group classification for the orders and families of flowering plants: APG IV. Bot. J. Linn. Soc. 181, 1-20. doi: 10.1111/boj.12385

Tillich, M., Lehwark, P., Pellizzer, T., Ulbricht-Jones, E. S., Fischer, A., Bock, R., et al. (2017). GeSeq - versatile and accurate annotation of organelle genomes. Nucleic Acids Res. 45, W6-W11. doi: 10.1093/nar/gkx391

Tippery, N. P., Philbrick, C. T., Bove, C. P., and Les, D. H. (2011). Systematics and phylogeny of Neotropical riverweeds (Podostemaceae: Podostemoideae). Syst. Bot. 36, 105-118. doi: 10.1600/036364411X553180

Ueda, M., Nishikawa, T., Fujimoto, M., Takanashi, H., Arimura, S.-I., Tsutsumi, N., et al. (2008). Substitution of the gene for chloroplast rps16 was assisted by generation of a dual targeting signal. Mol. Biol. Evol. 25, 1566-1575. doi: $10.1093 / \mathrm{molbev} / \mathrm{msn} 102$

van Royen, P. (1951). The Podostemaceae of the New World. (Harte: Medd. Bot, Museum Utrecht). Available at https://www.jstor.org/stable/41761589. Available at: https://books.google.com/books?id=IeV1SwAACAAJ.

Verdú, M. (2002). Age at maturity and diversification in woody angiosperms. Evolution 56, 1352-1361. doi: 10.1111/j.0014-3820.2002.tb01449.x 
Wakasugi, T., Tsudzuki, J., Ito, S., Nakashima, K., Tsudzuki, T., and Sugiura, M. (1994). Loss of all $n d h$ genes as determined by sequencing the entire chloroplast genome of the black pine Pinus thunbergii. PNAS 91, 97949798. doi: 10.1073/pnas.91.21.9794

Weng, M.-L., Blazier, J. C., Govindu, M., and Jansen, R. K. (2014). Reconstruction of the ancestral plastid genome in Geraniaceae reveals a correlation between genome rearrangements, repeats, and nucleotide substitution rates. Mol. Biol. Evol. 31, 645-659. doi: 10.1093/molbev/mst257

Wicke, S., Schneeweiss, G. M., dePamphilis, C. W., Müller, K. F., and Quandt, D. (2011). The evolution of the plastid chromosome in land plants: gene content, gene order, gene function. Plant. Mol. Biol 76, 273-297. doi: 10.1007/ s11103-011-9762-4

Wolfe, K. H., Morden, C. W., and Palmer, J. D. (1992). Function and evolution of a minimal plastid genome from a nonphotosynthetic parasitic plant. PNAS 89, 10648-10652. doi: 10.1073/pnas.89.22.10648

Wurdack, K. J., and Davis, C. C. (2009). Malpighiales phylogenetics: gaining ground on one of the most recalcitrant clades in the angiosperm tree of life. Am. J. Bot. 96, 1551-1570. doi: 10.3732/ajb.0800207

Xi, Z., Ruhfel, B. R., Schaefer, H., Amorim, A. M., Sugumaran, M., Wurdack, K. J., et al. (2012). Phylogenomics and a posteriori data partitioning resolve the Cretaceous angiosperm radiation Malpighiales. PNAS 109, 17519-17524. doi: $10.1073 /$ pnas. 1205818109
Xiao-Ming, Z., Junrui, W., Li, F., Sha, L., Hongbo, P., Lan, Q., et al. (2017). Inferring the evolutionary mechanism of the chloroplast genome size by comparing whole-chloroplast genome sequences in seed plants. Sci. Rep. 7, 1555. doi: 10.1038/s41598-017-01518-5

Xu, J.-H., Liu, Q., Hu, W., Wang, T., Xue, Q., and Messing, J. (2015). Dynamics of chloroplast genomes in green plants. Genomics 106, 221-231. doi: 10.1016/j. ygeno.2015.07.004

Young, N. D., and dePamphilis, C. W. (2005). Rate variation in parasitic plants: correlated and uncorrelated patterns among plastid genes of different function. BMC Evol. Biol. 5, 16. doi: 10.1186/1471-2148-5-16

Conflict of Interest Statement: The authors declare that the research was conducted in the absence of any commercial or financial relationships that could be construed as a potential conflict of interest.

Copyright (C) 2019 Bedoya, Ruhfel, Philbrick, Madriñán, Bove, Mesterházy and Olmstead. This is an open-access article distributed under the terms of the Creative Commons Attribution License (CC BY). The use, distribution or reproduction in other forums is permitted, provided the original author(s) and the copyright owner(s) are credited and that the original publication in this journal is cited, in accordance with accepted academic practice. No use, distribution or reproduction is permitted which does not comply with these terms. 